\title{
Stock Market Development and Economic Growth: A Comparative Evidence from two Emerging Economies in Africa - Nigeria and South Africa
}

\author{
Charity Ifunanya Osakwe ${ }^{1}$ and Amalachukwu Chijindu Ananwude ${ }^{1^{*}}$ \\ ${ }^{1}$ Department of Banking and Finance, Nnamdi Azikiwe University, Anambra State, PMB 5025, Awka, \\ Nigeria. \\ Authors' contributions \\ This research was carried out in collaboration between both authors. Author CIO was responsible for \\ study conceptualization and sourcing of relevant literature. She also wrote the first draft of the \\ manuscript and critically reviewed it thereafter. Author ACA sourced the data, performed the analysis \\ and interpreted the results. Both authors read and approved the final version of the manuscript.
}

Article Information

DOI: $10.9734 / \mathrm{ACRI} / 2017 / 38116$

Editor(s):

(1) Marco Muscettola, Economics, University of Bari, Italy.

Reviewers:

(1) Peter Ayunku, Niger Delta University, Niger.

(2) Der-Jang Chi, Chinese Culture University, Taiwan.

(3) Victoria Senibi, Covenant University, Nigeria.

(4) Linh H. Nguyen, Vietnam.

Complete Peer review History: http://www.sciencedomain.org/review-history/22182

Original Research Article

Received $12^{\text {th }}$ November 2017

Accepted $3^{\text {rd }}$ December 2017

Published $7^{\text {th }}$ December 2017

\section{ABSTRACT}

This study empirically explored the short run and long run relationship between stock market development and economic growth by comparing two leading emerging economies in Africa: Nigeria and South Africa from 1981 to 2015. Growth rate of gross domestic product was used to measure economic growth, while stock market development was surrogated by market capitalization ratio to gross domestic product and stock value traded ratio. Data were carefully sourced from World Bank development indicators of both countries. The ARDL co-integration divulged equilibrium long run relationship between stock market development and economic growth in Nigeria but not for South Africa. In both short and long run, there was a positive but insignificant relationship between stock market development and economic growth in Nigeria and South Africa. The granger causality analysis deduced that economic growth of South Africa is significantly affected by market capitalization but not so in Nigeria. The variation in economic 
growth owing to fluctuation in stock market development indices were observed to be insignificant for both Nigeria and South Africa. The study concluded that stock market development is relevant to economic growth as postulated in theoretical literature. Information disclosure in the stock markets of both countries need to be improve upon in an attempt to reducing information asymmetries. The availability of vital information of listed firms to insiders in the market hinders foreign investments. The non-availability of rating agencies and of a well-defined structure of regulation handicap investors from adequate assessment of firms' risk priori to investing their funds.

Keywords: Stock market development; economic growth; ADRL co-integration; market capitalization ratio; stock value traded ratio.

\section{INTRODUCTION}

The nexus between stock market development and economic growth has been extensively documented in literature consequent to the pioneering work of Schumpeter in 1912. Financial development with consideration to stock market development is a great driver to economic growth owing to stock market potential to pooling scarce resources for growth and development, particularly in emerging economies. Over the years, Nigeria and South Africa have experienced development in the financial system due to various reforms. The growth of South Africa financial sector was tremendously attributed to mining activities compared to Nigeria which was based on agricultural exports before the discovery of oil in Oloibiri on $15^{\text {th }}$ January, 1956. In the period before 1989, Africa could only boast of five stock markets in sub-Saharan region and three stock markets in the Northern region [1] but today, Africa has twenty nine (29) stock markets. The Johannesburg Stock Exchange (JSE) and Nigeria Stock Exchange (NSE) are considered the most vibrant and developed stock markets in the continent of Africa. The rise in the number of stock markets in Africa is a suggestion of embracing financial development by African countries in an attempt to attain a desired level of growth and development. African stock markets recorded unimpressive performance in 2016. Top of the gainers based trading activities at $16^{\text {th }}$ December, 2016 was Egypt stock market which was adjudged to have performed better followed by Zimbabwe, Casablanca and Mauritius stock exchanges. The Lusaka all share index is at the top of the losers' profile. This was strictly followed by Ghana stock exchange, Uganda stock exchange and Nigeria stock market.

Conventionally Nigeria has a large economy relative to South Africa but the level of poverty in Nigeria is higher than South Africa. The Nigeria population was estimated to be 186 million people in 2016, while that of South Africa was approximated to 56 million people. Nigerian economy needs to be substantially larger than South Africa before an average Nigerian will be as prosperous as an average South African [2]. The contribution of stock market to economic growth and development is greater in South Africa compared to Nigeria. In 2016, market capitalization of the Johannesburg Stock Exchange stood at USD 951, 320.33 million, while that of Nigeria was 29, 792.43 million. Similarly, market capitalization of domestic listed securities relative to gross domestic product for South Africa was $322.7 \%$, whereas it Nigeria, it was just $7.4 \%$. Stock value of traded of Johannesburg Stock Exchange was valued at USD 303 million compared to that of Nigeria with USD 169 million stock traded value in 2016. As the Nigerian economy continues its rapid integration with the global market place, it is inevitable that in parallel with the various public sector reforms that have been behind its increasing competitiveness, the nation will need to source significant amounts of funding and develop deep, efficient, and highly liquid capital markets in order to move the economy to the next growth phase [3]. In Nigeria, efforts have been made by market operators, regulators, and governments, to strengthen the stock market over the period since 1960 but the question as to where the country is today is a function of the strength and effectiveness of the regulatory framework on which the stock market is supposed to ride [4].

There have been time series empirical studies for both Nigeria and South Africa on stock market economic growth linkage ssee $[5,6,7,8,9]$ for Nigeria, $[10,11,12,13,14,15]\}$ but comparative analysis of these two leading emerging economies in Africa is completely lacking in literature. Comparative and Panel analysis have been studied in other continents of the world 
\{[16] for China, Russia, Brazil, South Africa and Argentina, [17] for Asia-Pacific region, [18] for 15 selected countries in Africa, [19] for South African Development Community which is comprise of 15 countries in Africa and [20] for Sub Saharan African countries among others). It is against this backdrop that this study explore the short run and long run relationship between stock market development and economic as well as the effect of stock market development on economic growth in a comparative context of Nigeria and South Africa. This study contributes to knowledge on the nexus between stock market development and economic by a comparative analysis of the two leading emerging economies in Africa: Nigeria and South Africa.

Having introduced the background, the remainder of this study is split as follows: section two reviewed prior literature. In section three, the methodological estimation was explained. The result from data analysis was detailed in section four, whereas the study was concluded in section five.

\section{CONCEPTUAL, FOUNDATION LITERATURE}

\section{THEORETICAL AND PRIOR}

The nexus between stock market development and economic growth is not complete without acknowledging [21] who laid the foundation to this subject matter. He asserted that a wellfunctioning financial system should promote economic growth through the selection of the productive investments which are the most likely to be successful and the efficient allocation of resources to these innovative technologies [22]. The stock market is the market for trading on medium and long term debt instruments. In the last two decades, studies on the stock market have received considerable attention from contemporary finance and economics literature resulting from its role in the provision of longterm, non-debt financial capital which enables companies to avoid over-reliance on debt financing, thus improving corporate debt-toequity ratio and also in the mobilization of resources for national growth [23]. The role of stock market in economic growth is vividly indisputable both theoretically and empirically. Although some analyst view stock market in developing countries as "casino" that have little positive effect on economic growth; evidence from empirical studies suggests that stock market may give a big boost to economic growth
[24]. [22] investigated the long run relationship between the development of banks and stock markets and economic growth. The study applied panel co-integration methodology to test the number of co-integrating vectors among these three variables for 5 developing countries. They also tested the direction of potential causality between stock market and economic development. The findings concluded the existence of a single co-integrating vector between stock market development and growth and of causality going from stock market development to economic growth and little evidence of reverse causation as well as bidirectional causality.

Theoretically, stock market is expected to sour economic growth owing to capital mobilization from surplus and subsequent allocation to deficit units for production which translate to overall output of the economy. The stock market is expected to encourage savings by providing individuals with an additional financial instrument that may better meet their risk preferences and liquidity needs [1]. A well-functioning stock market enhances firms' access to finance to business expansion as their share would be easily exchanged for investors' money without much encumbrance and the finance from stock market is much more lowly compared to the banking system credits which are mainly short term bases, and in few cases medium term [25]. The finance led growth school of thought argues that the financial system is not relevant for economic growth; another stresses the necessity of financial system in mobilizing savings, allocating capital, exerting corporate control, and risk management [5]. In the support of the positive association between stock market and economic growth, [26] provided empirical evidence in affirmation of [21] theory and hypothesized that financial liberalization and stock market development would promote economic growth through their effects on the growth rate of savings, investment, and thus economic growth [6]. [27] proved the existence of a positive correlation between financial development through stock market and economic growth flowing from financial development to economic growth. The proponents of the positive influence of stock market on economic has dominated empirical findings from across the world relative to independence of economic growth on stock market as well as the no connection between stock market and economic growth. 
Empirical studies of $[28,29,30,31,32,33,34,35$, $36,37,38,39,23,40$ ] and [41] addressed single country analysis in Nigeria and South Africa. All the same, in this study, the review of prior literatures were specifically concentrated on cross country/panel analysis as against single country analysis. This is on notion that this study is based on comparative analysis and evidence from cross country assessment would provide better evaluation. [16] examined the extent of balanced and sustained growth in selected 14 Asia-Pacific countries. It analysed data on Morgan Stanley Capital International (MSCl) returns, GDP growth, and Human Development Index (HDI) to rank and correlate the overall performance of each country during the 19932009 period. Gini Index and CPI are also included to provide added insights. The results showed that developing countries like India, Indonesia, Pakistan, and Sri Lanka are at the top on most of the financial and economic indicators, while Japan is the lowest except on HDI, where the bottom rankings goes to India, Indonesia and Pakistan. Overall, the results indicated no significant relationships between a country's stock market returns and its GDP growth. Nonetheless, the results suggested that for balanced and sustainable well-being, economic growth in the less-developed countries need to be matched by concomitant improvements in social welfare, income distribution, transparency and accountability. [18] provided further evidence on the relationship between stock market capitalization and economic growth using data from a sample of African countries with wellfunctioning stock markets. A dynamic panel estimation approach was employed with a view to assessing the relative impact of stock market capitalization on economic growth in Africa. The results from the study revealed that raising stock market capitalization by a marginal average of $10 \%$ induces growth on average by $5.4 \%$ in countries studied.

[42] empirically examined the effect of stock market development on economic growth of two Asian regions namely South Asia and East Asia. The study used market capitalization, total value traded ratio and turnover ratio as indicators of stock market development while GDP per capita growth rate is used for measuring economic growth. The linear panel data methodology was applied over the annual data of 1996-2015 to study the phenomenon. The effect was then compared across the countries of both regions. Empirical findings indicated that stock market development contributes to some extent in the economic growth of South Asian region but its impact on East Asian region found to be insignificant. Using a pooled panel data set from nine developing countries within the South African Development Community (SADC) region from 1980 to 2011, [19] assessed the relationship between stock market development and economic growth, and macroeconomic determinants of stock market development through the random effect model. The results suggested that there is a strong link between stock market development and economic growth. The evidences obtained support the view that a well-developed and functioning stock market can boost economic growth through enhanced capital accumulation and better resource allocation, particularly in developing countries.

[43] explored the dynamic relationships between stock market development and economic growth in selected forty-seven countries of the world. Applying developments in the analysis of panels with a small time dimension to estimate vector autoregressions for a set of forty-seven countries with annual data over the 1980-1995 period. After describing the state of current theory on the role of stock markets in promoting growth and considering insights that can be gained from a pure cross-sectional empirical approach, they study presented VAR evidence of leading roles for stock market liquidity and the intensity of activity in traditional financial intermediaries in per capita output. The findings underscored the potential gains associated with developing deep and liquid financial markets in an increasingly global economy. [44] studied the effect of stock market development on economic growth by panel data techniques by fixed effects and random effects by applying Hausamn test for 20 Lower-Middle Income countries for the time period of 1990 to 2012. Overall results suggested that there is positive and significant effect of stock market development on economic growth. The study also measured the exact impact of stock market development on growth of economy by control variables such as financial depth, investment, foreign direct investment, trade openness and inflation but stock market development which is turnover ratio (ratio of total value traded to the total value of listed shares) has insignificant relationship with economic growth.

[45] ascertained the relationship between stock market development and economic growth of two Asian developing countries: Pakistan and Bangladesh, after the liberalization period of 
1990s. The relationship measured were in terms of size (market capitalization), liquidity (total value of stocks traded and stock turnover ratio) and volume (total number of companies listed in the stock exchange of each of the country). The econometric results of the study by employing the regression analysis showed that Pakistan stock markets contribute to the economic growth in terms of the large size of its stock market whereas Bangladesh stock market contributes to the economic growth in terms of the liquidity of its stock market. Bangladesh economic growth was found to be comparatively better than economic growth of Pakistan. The study revealed that the stock markets in Pakistan and Bangladesh do not play a major role in the economic growth but rather, these financial institutions are the driving forces for the economic growth of the country. [46] used the panel data approach with fixed effects to differentiate the long-run rate from short-run level effect of stock market development on economic growth against a sample of 70 countries over the period 19751992. The empirical evidence indicated that development of stock markets has significant positive effects on both the long-run growth rate and short-run level of real GDP per capita. Furthermore, they found that the influence of stock market is mainly through the channel of productivity improvement, rather than capital formation. The overall findings suggested that stock markets have a stronger impact on growth rate for low-income countries.

Empirically, based on the data for 17 emerging market and 10 developed market economies during the 12 years' period, from $2000-2011$, [47] used the generalized method of momentum (GMM) for dynamic panel data and estimated the relationship between stock market development and economic Growth. The key findings of the study revealed that there exists statistically significant relationship between stock market development and economic growth both directly, as well as indirectly by boosting investment behaviour. The results also indicated robustly that stock market development is an important wheel for economic growth. [48] determined the role of stock markets in economic growth for four Asian countries namely Bangladesh, India, China and Singapore. Annual time series cross country data over the period 1991 to 2012 and autoregressive distributed lag bound testing approaches an analytical technique were used. The results suggested that there is long-term cointegration among economic growth, foreign direct investment, stock market development and inflation. The long-term elasticity estimates of the stock market development in all countries show expected sign but statistically significant only in China and Singapore. In the short-run, stock market also has positive relation to economic growth in all countries but significant only in India and China. The empirical findings of the study revealed that stock market development and foreign direct investment inflows play vital roles in the process of economic growth and development in four Asian countries.

[49] provided a comparative analysis on stock market performance and augmentation of frontier economies: Nigeria and Mauritius. Using a Paired-Samples T-test statistical modus operandi, data of market capitalization and gross domestic product were obtained from the Central Bank of Nigeria statistical bulletin and annual Financial Services Commission statistical bulletin of Mauritius during 2006-2010. The findings revealed that stock market performance for Mauritius was superior to Nigeria and same for GDP. In addition, the negativity showed that stock market performance has a negative impact on economic progress in Nigeria and Mauritius due to the fact that frontier markets give attention to money market while relegating stock market to the background. [50] evaluated the effect of Islamic and conventional stock markets upon the macroeconomic performance in Malaysia. Real GDP was used to represent economic growth; while Islamic market capitalisation ratio and conventional market capitalisation ratio were used to indicate the Islamic and conventional stock market development, respectively. The results showed that there is a bidirectional relationship between Islamic stock markets and economic growth in Malaysia, and the contribution towards the economic growth seemed to be indirectly through its impact on investment. On the other hand, there was a unidirectional relationship between conventional stock markets and economic performance in Malaysia, in which the development of conventional stock market causes the growth.

\section{METHODOLOGY AND DATA}

With the intent of determining the short run and long run relationship between stock market development and economic growth based on comparative analysis of Nigeria and South Africa, the Autoregressive Distributive Lag (ARDL) model approach was applied using time series data from 1981 to 2015. The granger causality analysis was employed to determine the effect of 
stock market development on economic growth of both countries. The data were sourced from World Bank development indicators. Before estimating the model, data were scrutinize for stationarity through Augmented Dickey-Fuller (ADF) and Phillips Perron (PP). Size of the stock market via Market Capitalization Ratio to Gross Domestic Product (MKTCR) and liquidity through Stock Value Traded Ratio to Gross Domestic Product (SVTR) and Turnover Ratio (TUNR) were used to measure the degree of development in the stock market, while economic growth was indicated by Gross Domestic Product Growth Rate (GDPGR).

\subsection{Empirical Specification of Model}

With adherence to linear regression model, we modified the model of [45] for a comparative analysis of Pakistan and Bangladesh. In the light of this, stock market development and economic growth model relationship in Nigeria and South Africa is expressed as:

$$
Y_{t}=\beta_{0}+\sum_{i=1}^{p} \beta_{i}+Z_{i-1}+\varphi_{t}
$$

Where: economic growth based on gross domestic product growth rate is symbolized by $Y_{t}$; intercept of the regression equation was denoted by $\beta_{0}$, stock market development measures coefficient were detailed by $\beta_{i}$ stock market development is reflected by $Z_{i}$ through: mktcr $=$ market capitalization ratio to GDP, svtr $=$ stock value traded, tunr $=$ turnover ratio and $\varphi_{t}$ depicting error term. The transformation of the model to econometric format for both Nigeria and South Africa results to thus:

$$
\begin{aligned}
G D P G R_{t}=\beta_{0}+ & \beta_{1} M K T C R_{t}+\beta_{2} S V T R_{t} \\
& +\beta_{3} T U N R_{t}+\varphi_{t}
\end{aligned}
$$

The correlation analysis for stock market development indices revealed that two measurement of liquidity: stock value traded ratio and turnover ratio for Nigeria and South Africa stock markets were highly correlated. For Nigeria, the correlation between stock value traded ratio and turnover ratio was 0.83 , whereas that of South Africa unveils 0.92 (see Tables 15 and 16). This is an indication that either stock value traded ratio or turnover ratio can effectively measure the liquidity of the market, hence the removal of turnover ratio from the equ. 2 to avoid bias in the result of the regression analysis thus:

$$
\begin{aligned}
\operatorname{GDPGR}_{t}=\beta_{0}+ & \beta_{1} M K T C R_{t}+\beta_{2} S V T R_{t} \\
& ++\varphi_{t}
\end{aligned}
$$

\section{RESULTS AND DISCUSSION}

We began the analysis by looking at the descriptive structures of the data. The descriptive features of Nigerian and South Africa data were condensed in Tables 1 and 2. Descriptive properties of the data visa viz: mean, median, minimum and maximum value, standard deviation, Skewness, Kurtosis, Jarque-Bera, Sum Sq. Dev. and number of observations were elucidated. On the premise of the Nigeria data, the mean divulged 3.67 for GDPGR, 13.82 for MKTCR, 1.29 for SVTR and 7.46 for TUNR but for South Africa, 2.27 for GDPGR, 167.2 for MKTCR, 32.62 for SVTR and 16.92 for TUNR. The median for South Africa are 2.60, 157.6, 27.99 and 18.82 for GDPGR, MKTCR, SVTR and TUNR respectively while that of Nigeria are 4.28, 10.39, 0.42 and 6.10. The minimum and maximum values respectively for Nigeria's capital market are 33.74 and -13.13 for GDPGR, 51.00 and 3.35 for MKTCR, 0.04 and 2.13 for SVTR and 1.05 and 6.31 for TUNR but for South Africa it was recorded as 5.59 and -2.14 for GDPGR, 62.6 and 59.4 for MKTCR, 2.15 and 27.66 for SVTR and 3.33 and 11.99 for TUNR. The standard deviation shows that South Africa capital performed better in market capitalization ratio GDP, stock value traded ratio to GDP and turnover ratio when compared to Nigeria's capital market. In terms of the peakedness of the variables measured by Kurtosis statistic, Nigeria data were leptokurtic in nature as the Kurtosis values were greater than 3, while South Africa data were observed not to be leptokurtic in nature as evidenced by the less than 3 values of the Kurtosis statistic. The skewness statistic reveals that all Nigeria data are positively skewed towards normality but for South Africa only GDPGR was not positively skewed towards normality. The $p$-value of the JarqueBera suggests that all the variables of interest in Nigeria were normally distributed and devoid of any outlier capable of affecting result as shown by the significant $p$-values but for South Africa, all the variables based on World Bank development indicators, were not normally distributed. Consequently, the Shapiro-wilk normality test was conducted for all the South Africa data. At this time it was observed that the South Africa data were all normally distributed as depicted by the significant $p$-values of the Shapiro-wilk statistic in Table 3. 
Osakwe and Ananwude; ACRI, 11(1): 1-15, 2017; Article no.ACRI.38116

Table 1. Descriptive structure of Nigeria data

\begin{tabular}{|c|c|c|c|c|c|c|c|c|c|c|}
\hline & Mean & Median & Maximum & Minimum & Std. Dev. & Skewness & Kurtosis & Jarque-Bera & P-value & Obs. \\
\hline GDPGR & 3.67 & 4.28 & 33.74 & -13.13 & 7.67 & 1.18 & 8.59 & 53.70 & 0.00 & 35 \\
\hline MKTCR & 13.82 & 10.39 & 51.00 & 3.35 & 11.36 & 1.45 & 4.80 & 17.05 & 0.00 & 35 \\
\hline SVTR & 1.29 & 0.42 & 10.43 & 0.04 & 2.13 & 3.25 & 13.32 & 216.83 & 0.00 & 35 \\
\hline TUNR & 7.46 & 6.10 & 34.79 & 1.05 & 6.31 & 2.54 & 11.46 & 141.90 & 0.00 & 35 \\
\hline
\end{tabular}

Table 2. Descriptive structure of South Africa data

\begin{tabular}{|c|c|c|c|c|c|c|c|c|c|c|}
\hline & Mean & Median & Maximum & Minimum & Std. Dev. & Skewness & Kurtosis & Jarque-Bera & P-value & Obs. \\
\hline GDPGR & 2.27 & 2.60 & 5.59 & -2.14 & 2.231 & -0.42 & 2.20 & 1.96 & 0.38 & 35 \\
\hline MKTCR & 167.2 & 157.6 & 276.6 & 62.6 & 59.4 & 0.33 & 2.12 & 1.79 & 0.41 & 35 \\
\hline SVTR & 32.62 & 27.99 & 86.08 & 2.15 & 27.66 & 0.38 & 1.65 & 3.51 & 0.17 & 35 \\
\hline TUNR & 16.92 & 18.82 & 41.98 & 3.33 & 11.99 & 0.20 & 1.61 & 3.05 & 0.22 & 35 \\
\hline
\end{tabular}

Source: Data output via E-views 9.0 
Table 3. Shapiro-wilk statistic normality test for South Africa data

\begin{tabular}{lll}
\hline Data & Shapiro-wilk statistic & P-value \\
\hline GDPGR & 0.945469 & 0.082241 \\
MKTCR & 0.954461 & 0.050293 \\
SVTR & 0.871016 & 0.000718 \\
TUNR & 0.866457 & 0.000557 \\
\hline
\end{tabular}

\subsection{Test for Stationarity}

The stationarity scrutiny was handled with Augmented Dickey-Fuller (ADF) at level and first difference form to ensure that the data comply with stationarity requirement and prevent the occurrence of spurious regression result. The
ADF for Nigeria at level and first difference are presented in Tables 4 and 5, while that of South Africa is detailed in Tables 6 and 7.

For Nigeria data it was observed that all the variables were not stationary at level for except GDPGR but became stationary at first differencing. However, for South Africa GDPGR, MKTCR and SVTR were found to me stationary at level. All the data for South Africa also became stationary at first difference, which gives freedom for testing the number of co-integrating equations in the models. World Bank development indicators data for South Africa are more stationary at level for compared to that of Nigeria.

Table 4. ADF Nigeria test result at level

\begin{tabular}{lllll}
\hline Variables & ADF test statistic & $\begin{array}{l}\text { Test critical } \\
\text { value at 1\% }\end{array}$ & $\begin{array}{l}\text { Test critical } \\
\text { value at 5\% }\end{array}$ & Connotation \\
\hline GDPGR & $-4.810838(0.00)^{\star}$ & -3.639407 & -2.951125 & Stationary \\
MKTCR & $-2.509275(0.12)$ & -3.639407 & -2.951125 & Not Stationary \\
SVTR & $4.214462(1.00)$ & -3.711457 & -2.981038 & Not Stationary \\
TUNR & $-2.591197(0.10)$ & -3.639407 & -2.951125 & Not Stationary \\
\hline \multicolumn{5}{c}{ Source: Data output via E-views 9.0.}
\end{tabular}

Table 5. ADF Nigeria test result at first difference

\begin{tabular}{lllll}
\hline Variables & ADF test statistic & $\begin{array}{l}\text { Test critical } \\
\text { value at 1\% }\end{array}$ & $\begin{array}{l}\text { Test critical } \\
\text { value at 5\% }\end{array}$ & Connotation \\
\hline GDPGR & $-8.688280(0.00)^{*}$ & -3.646342 & -2.954021 & Stationary \\
MKTCR & $-6.327757(0.00)^{*}$ & -3.646342 & -2.954021 & Stationary \\
SVTR & $-5.593785(0.00)^{*}$ & -3.653730 & -2.957110 & Stationary \\
TUNR & $-6.595290(0.00)^{*}$ & -3.646342 & -2.954021 & Stationary \\
\hline
\end{tabular}

Source: Data output via E-views 9.0

Table 6. ADF South Africa test result at level

\begin{tabular}{lllll}
\hline Variables & ADF test statistic & $\begin{array}{l}\text { Test critical } \\
\text { value at 1\% }\end{array}$ & $\begin{array}{l}\text { Test critical } \\
\text { value at 5\% }\end{array}$ & Connotation \\
\hline GDPGR & $-4.798369(0.00)^{\star}$ & -4.252879 & -3.548490 & Stationary \\
MKTCR & $-4.714965(0.00)^{*}$ & -4.252879 & -3.548490 & Stationary \\
SVTR & $-3.847648(0.02)^{\star *}$ & -4.284580 & -3.562882 & Stationary \\
TUNR & $-2.573558(0.29)$ & -4.252879 & -3.548490 & Not Stationary \\
\hline
\end{tabular}

Source: Data output via E-views 9.0

Table 7. ADF South Africa test result at first difference

\begin{tabular}{lllll}
\hline Variables & ADF test statistic & $\begin{array}{l}\text { Test critical } \\
\text { value at 1\% }\end{array}$ & $\begin{array}{l}\text { Test critical } \\
\text { value at 5\% }\end{array}$ & Connotation \\
\hline GDPGR & $-7.647935(0.00)^{*}$ & -3.646342 & -2.954021 & Stationary \\
MKTCR & $-7.021976(0.00)^{*}$ & -3.653730 & -2.957110 & Stationary \\
SVTR & $-5.658255(0.00)^{*}$ & -3.646342 & -2.954021 & Stationary \\
TUNR & $-6.587018(0.00)^{*}$ & -3.646342 & -2.954021 & Stationary \\
\hline
\end{tabular}

Source: Data output via E-views 9.0 


\subsection{Model Residual and Stability Test}

We performed the residual (serial correlation and heteroskedasticity), stability (Ramsey specification) and correlation matrix. From the serial correlation output in Table 8 , the model as specified is devoid of correlation serially ( $p$-value $>$ 0.05). Heteroskedasticity issue was not observed for the model as shown in Table $9(\mathrm{p}-$ value $>0.05)$. Table 10 depicts that the model was well specified for Nigeria and South Africa ( $p$-value $>0.05)$. Furthermore, there problem of multicollinearity by virtue of amalgamating size and liquidity of the market in the same equation via market capitalization to GDP, staock value traded ratio to GDP and turnover ratio as envisaged in Tables 11 and 12 which led to the removal of turnover ratio from the equation and subsequent estimations.

\subsection{Auto-Regressive Distributed Lag (ARDL) Models}

The ARDL was used as opposed to the Johansen co-integration on the reason that the data were not integrated at the same order. The ARDL approach takes into account the nonintegration of data at the same order and eliminates bias associated with such mixed order of integration. The ARDL in Table 13 reveals that there is a long run relationship between stock market development and economic growth in Nigeria but no long run relationship between stock market development and economic growth in South Africa. The f-statistic for Nigeria (7.808411) is greater than the upper and lower bound test values of 4.85 and 3.97 respectively at $5 \%$ level of significance, while that of South Africa (4.347834) is less than the upper and lower bound test values of 4.85 and 3.97 accordingly at $5 \%$ level of significance. A further analysis of the nature of relationship in the long run (see Tables 15 and 16) show that stock market capitalization to GDP and stock value traded ratio for Nigeria and South Africa have positive but insignificant relationship with economic growth even though the error correction mechanism is positively signed and reveal the tendency of the model to correct to equilibrium following disequilibrium in previous years.

Table 8. Serial correlation LM test

\begin{tabular}{lcc}
\hline Country & F-statistic & Prob. \\
\hline Nigeria & 0.510092 & 0.6057 \\
South Africa & 1.188627 & 0.3190 \\
\hline \multicolumn{2}{c}{ Source: Data output via E-views 9.0}
\end{tabular}

Table 9. Heteroskedasticity test

\begin{tabular}{lll}
\hline Country & F-statistic & Prob. \\
\hline Nigeria & 0.104038 & 0.9571 \\
South Africa & 0.086864 & 0.7701 \\
\hline
\end{tabular}

Source: Data output via E-views 9.0

Table 10. Ramsey reset specification

\begin{tabular}{lllc}
\hline Country & Value & df & Prob. \\
\hline Nigeria & 0.817646 & $(1,30)$ & 0.3731 \\
South Africa & 0.001045 & $(1,30)$ & 0.9722 \\
\hline \multicolumn{4}{c}{ Source: } \\
\hline \multicolumn{4}{c}{ Data output via E-views 9.0}
\end{tabular}

Table 11. Multicollinearity test Nigeria data

\begin{tabular}{lllll}
\hline & GDPGR & MKTCR & SVTR & TUNR \\
\hline GDPGR & 1.000000 & 0.234691 & 0.244453 & 0.249050 \\
MKTCR & 0.234691 & 1.000000 & 0.673818 & 0.344895 \\
SVTR & 0.244453 & 0.673818 & 1.000000 & 0.834559 \\
TUNR & 0.249050 & 0.344895 & 0.834559 & 1.000000 \\
\hline
\end{tabular}

Source: Data output via E-views 9.0

Table 12. Multicollinearity test South Africa data

\begin{tabular}{lcccc}
\hline & GDPGR & MKTCR & SVTR & TUNR \\
\hline GDPGR & 1.000000 & 0.220138 & 0.269129 & 0.281616 \\
MKTCR & 0.220138 & 1.000000 & 0.845685 & 0.629282 \\
SVTR & 0.269129 & 0.845685 & 1.000000 & 0.922322 \\
TUNR & 0.281616 & 0.629282 & 0.922322 & 1.000000 \\
\hline
\end{tabular}

Source: Data output via E-views 9.0 
Table 13. Bound test for Nigeria's GDPGR, MKTCR and SVTR

\begin{tabular}{llll}
\hline F-Statistic & Lower bound at 5\% & Upper bound at 5\% & Implication \\
\hline 7.808411 & 3.79 & 4.85 & Null Hypothesis Rejected \\
\hline \multicolumn{4}{c}{ Source: Data output via E-views 9.0} \\
\hline
\end{tabular}

Table 14. Bound test for South Africa's GDPGR, MKTCR and SVTR

\begin{tabular}{clll}
\hline F-Statistic & Lower bound at 5\% & Upper bound at 5\% & Implication \\
\hline 4.347834 & 3.79 & 4.85 & Null Hypothesis Accepted \\
\hline \multicolumn{4}{r}{ Source: Data output via E-views 9.0} \\
\hline
\end{tabular}

Table 15. ARDL error correction for Nigeria's GDPGR, MKTCR and SVTR

\begin{tabular}{llcll}
\hline \multicolumn{5}{c}{ Co-integration form } \\
\hline Variable & Coefficient & Std. error & t-statistic & Prob. \\
\hline D(MKTCR) & 0.034228 & 0.148029 & 0.231227 & 0.8187 \\
D(SVTR) & 0.477788 & 0.786299 & 0.607641 & 0.5480 \\
CointEq(-1) & -0.804688 & 0.166421 & -4.835261 & 0.0000 \\
\hline \multicolumn{5}{c}{ Long run coefficient } \\
\hline MKTCR & 0.042536 & 0.183247 & 0.232124 & 0.8180 \\
SVTR & 0.593756 & 0.969974 & 0.612136 & 0.5451 \\
C & 2.897093 & 2.498985 & 1.159308 & 0.2555 \\
\hline
\end{tabular}

Source: Data output via E-views 9.0

Table 16. ARDL error correction for South Africa's GDPGR, MKTCR and SVTR

\begin{tabular}{llcll}
\hline \multicolumn{5}{c}{ Co-integration form } \\
\hline Variable & Coefficient & Std. error & t-statistic & Prob. \\
\hline D(MKTCR) & 0.000294 & 0.011534 & 0.025517 & 0.9798 \\
D(MKTCR $(-1))$ & 0.018152 & 0.011176 & 1.624145 & 0.1160 \\
D(SVTR) & 0.003143 & 0.029249 & 0.107440 & 0.9152 \\
CointEq(-1) & -0.640301 & 0.182380 & -3.510811 & 0.0016 \\
\hline \multicolumn{5}{c}{ Long run coefficient } \\
\hline MKTCR & 0.007006 & 0.023501 & 0.298131 & 0.7679 \\
SVTR & 0.004908 & 0.045501 & 0.107865 & 0.9149 \\
C & 0.786481 & 2.700925 & 0.291190 & 0.7731 \\
\hline
\end{tabular}

Source: Data output via E-views 9.0

The short run relationship as detail in Table 17 and 18 infer that market capitalization ratio to GDP and stock value traded ratio have positive but insignificant relationship with economic growth for both Nigeria and South Africa. When stock market development variables are held constant, economic growth in Nigeria would amount $2.33 \%$, while that of South Africa is $0.50 \%$. A unit rise in market capitalization ratio to GDP increases economic growth in Nigeria by $0.03 \%$, whereas that of South Africa is $0.0003 \%$. Economic Nigeria would rise by $0.48 \%$ following a percentage increase in stock value traded ratio, while that of South Africa would record $0.003 \%$. The Durbin Watson test of autocorrelation for both countries met the benchmark of 2.0 thus no autocorrelation in the model. The Adjusted Rsquare reveals that $0.9 \%$ variation in economic growth in Nigeria was attributed to fluctuation in stock market development indices but that of South Africa $15.27 \%$ which is far greater than that of Nigeria. from the $p$-value of the f-statistics for both countries, stock market development indices did not significantly explained the variation in economic growth within the period studied. From the result in Tables 17 and 18, economic growth in South Africa tends to be influenced more by stock market contributes compared to Nigeria.

\subsection{Stock Market Effect on Economic Growth}

To comparatively assess the effect of stock market indicators of Nigeria and South Africa on 
economic growth, the granger causality test was employed. A lag order of one was selected owing to that fact that data applied in this study were time series based. The result of the granger effect assessment for Nigeria and South Africa are summarized in Tables 19 ad 20. From Table 19 , there is no unidirectional or bidirectional causal relationship between market capitalization ratio to GDP and economic growth in Nigeria at $5 \%$ level of significance whereas for South Africa as depicted in Table 20 reveals a unidirectional relationship between market capitalization ratio to GDP and economic growth in South Africa running from market capitalization ratio to GDP to economic growth at $5 \%$ significance level. It would construed from the results in Table 19 ad 20 that market capitalization ratio to GDP has a significant effect on economic growth of South Africa but has no significant effect on the economic growth of Nigeria. In the second place is the causal effect of stock value traded ratio on economic growth. It is vivid in Tables 19 ad 20 that stock value traded ratio has no significant effect on economic growth of both Nigeria and South Africa as there is no evidence of a causal relationship at $5 \%$ level of significance between stock value traded ratio and economic growth of both countries.

\subsection{Discussing the Finding in Relation to Prior Literature}

The result of a positive relationship between market capitalization ratio to GDP for Nigeria and South Africa as shown in Tables 17 and 18 is indication that a unit increase in market capitalization ratio to GDP influences economic growth and in line with a priori expectation. It would be inferred from the result that the size of the stock market affects the liquidity of the market. This supports the results of previous studies in Nigeria via $[28,29,30,31$,

Table 17. ARDL regression result: Nigeria's GDPGR, MKTCR and SVTR

\begin{tabular}{lllll}
\hline Variable & Coefficient & Std. error & t-statistic & Prob. \\
\hline GDPGR(-1) & 0.195312 & 0.166421 & 1.173607 & 0.2498 \\
MKTCR & 0.034228 & 0.148029 & 0.231227 & 0.8187 \\
SVTR & 0.477788 & 0.786299 & 0.607641 & 0.5480 \\
C & 2.331255 & 2.018379 & 1.155013 & 0.2572 \\
\hline R-squared & 0.099190 & Mean dependent var & & 4.166765 \\
Adjusted R-squared & 0.009109 & S.D. dependent var & & 7.199550 \\
S.E. of regression & 7.166685 & Akaike info criterion & 6.886894 \\
Sum squared resid & 1540.841 & Schwarz criterion & 7.066466 \\
Log likelihood & -113.0772 & L Hannan-Quinn criter. & 6.948134 \\
F-statistic & 1.101117 & Durbin-Watson stat & 2.051126 \\
Prob (F-statistic) & 0.363989 & & \\
\hline
\end{tabular}

Source: Data output via E-views 9.0

Table 18. ARDL regression result: South Africa's GDPGR, MKTCR and SVTR

\begin{tabular}{lllll}
\hline Variable & Coefficient & Std. error & t-statistic & Prob. \\
\hline GDPGR(-1) & 0.359699 & 0.182380 & 1.972249 & 0.0589 \\
MKTCR & 0.000294 & 0.011534 & 0.025517 & 0.9798 \\
MKTCR(-1) & 0.022344 & 0.011695 & 1.910587 & 0.0667 \\
MKTCR(-2) & -0.018152 & 0.011176 & -1.624145 & 0.1160 \\
SVTR & 0.003143 & 0.029249 & 0.107440 & 0.9152 \\
C & 0.503585 & 1.732342 & 0.290696 & 0.7735 \\
\hline R-squared & 0.285141 & Mean dependent var & 2.257273 \\
Adjusted R-squared & 0.152759 & S.D. dependent var & 2.184504 \\
S.E. of regression & 2.010742 & Akaike info criterion & 4.397850 \\
Sum squared resid & 109.1632 & Schwarz criterion & 4.669942 \\
Log likelihood & -66.56452 & L Hannan-Quinn criter. & 4.489401 \\
F-statistic & 2.153933 & Durbin-Watson stat & 2.044138 \\
Prob (F-statistic) & 0.089296 & & \\
\hline
\end{tabular}


Table 19. Granger causality result for Nigeria's GDPGR, MKTCR and SVTR

\begin{tabular}{lllll}
\hline Null hypothesis & Obs & F-statistic & Prob. & Remarks \\
\hline MKTCR does not Granger Cause GDPGR & \multirow{2}{*}{34} & 0.10359 & 0.7479 & No Causality \\
GDPGR does not Granger Cause MKTCR & \multirow{2}{*}{34} & 0.43130 & 0.5162 & No Causality \\
SVTR does not Granger Cause GDPGR & \multirow{2}{*}{0.88522} & 0.3540 & No Causality \\
GDPGR does not Granger Cause SVTR & & 0.47624 & 0.4953 & No Causality \\
\hline
\end{tabular}

Source: Data output via E-views 9.0

Table 20. Granger causality result for South Africa's GDPGR, MKTCR and SVTR

\begin{tabular}{lcccl}
\hline Null hypothesis & Obs & F-statistic & Prob. & Remarks \\
\hline MKTCR does not Granger Cause GDPGR & \multirow{2}{*}{34} & 5.00431 & 0.0326 & Causality \\
GDPGR does not Granger Cause MKTCR & \multirow{2}{*}{34} & 0.00794 & 0.9296 & No Causality \\
SVTR does not Granger Cause GDPGR & \multirow{2}{*}{$\begin{array}{l}1.55649 \\
\text { GDPGR does not Granger Cause SVTR }\end{array}$} & 0.32515 & 0.2215 & No Causality \\
Source: Data output via E-viows 9.0 & & No Causality \\
\hline
\end{tabular}

Source: Data output via E-views 9.0

32,33,34,35,36,37]. For South Africa, it agrees with the findings of $[12,14]$ and [38]. Nevertheless, the positive relationship between market capitalization ratio to GDP refutes the empirical results of $[13,39,23,40]$ and [41].

In term of the liquidity of the capital market, Tables 17 and 18 envisage a positive relationship between economic growth and stock value traded ratio confirm to a priori expectation for both Nigeria and South Africa. This result brings to light that the liquidity of the stock market increases the availability of funds for productive economic activities which in turn enhance economic growth. The ease with which securities in the capital market are converted to liquid cash results in increase investment in the market. This is in tandem with the findings of $[28,41,30,35,39]$ and [13]. That notwithstanding, the result would not confirm the findings of $[38,12,37,36,34,23]$ and [32] on the negative linkage between capital market liquidity and economic growth.

The ARDL results in Tables 13 and 14 for Nigeria and South Africa reveals the existence of a long run relationship between capital market development and economic growth. This result point to finance led growth hypothesis that stock market is growth inducing especially for emerging economies. Sound policy implementation on the stock market will vividly enhance economic growth of Nigeria. The granger causality estimation in Tables 19 and 20 for Nigeria and South Africa show that market capitalization ratio and stock value traded ratio does not stimulate economic growth in Nigeria while market capitalization ratio spurs economic growth in South Africa. This would be that South
Africa stock market size and liquidity position are bigger and better than that of Nigeria; South Africa is a middle income country with a lot of economic infrastructure already in place; South Africa per capita income is much higher than that of Nigeria. This is an indication that the South Africa stock market is more developed compared to that of Nigeria. In other words, the South Africa stock market contributes to economic growth of South Africa while the economic growth of Nigeria tends not to be influenced by the stock market operations.

\section{CONCLUSION AND LIMITATIONS}

This study empirically and comparatively explore the short run and long run relationship between stock market development and economic growth in Nigeria and South Africa from 1981 to 2015. Growth rate of gross domestic product was used to measure economic growth, while stock market development was surrogated by market capitalization ratio to gross domestic product, stock value traded ratio to ratio to gross domestic product and turnover ratio. However, the correlation analysis detected the presence of multicollinearity if stock value traded ratio to ratio to gross domestic product and turnover ratio were included in the same model thus the removal of turnover ratio. The ARDL cointegration divulge equilibrium long run relationship between stock market development and economic growth in Nigeria but not for South Africa. In both short and long run, there is a positive but insignificant relationship between stock market development and economic growth in Nigeria and South Africa. The granger causality analysis deduce that economic growth of South Africa is significantly affected by market 
capitalization but not so in Nigeria which led to inference that stock market in South Africa is more developed compared to that of Nigeria. The variation in economic growth owing to fluctuation in stock market development indices were observe to be insignificant for both Nigeria and South Africa. The study concluded that stock market development is relevant to economic growth as postulated in theoretical literature. Information disclosure in the stock markets of both countries need to be improve upon in an attempt to reducing information asymmetries. The availability of vital information of listed firms to insiders in the market hinders foreign investments. The non-availability of rating agencies and of a well-defined structure of regulation handicap investors from adequate assessment of firms' risk priori to investing their funds.

The result of the study would reveal the strength and depth, growth of the market and rate of transaction in each capital market to both local and foreign investors who have intentions of investing in Nigeria and South Africa stock markets. The majority of the previous studies have mainly used either the residual-based cointegration test associated with Engle \& Granger (1987) or the maximum likelihood test based on Johansen (1988) and Johansen \& Juselius (1990). Yet it is now well known that these cointegration techniques may not be appropriate when the sample size is too small \{see [14]\}. It is against this backdrop, this study contributes to knowledge by the application of the newly developed ARDL-Bounds testing approach to investigate short run and long run relationship between stock market development and economic growth by comparing two leading emerging economies in Africa: Nigeria and South Africa using broad time series data from 1981 to 2015.

One major limitation to this study is the indisposition in ascertaining the influence of turnover ratio on economic growth of both countries owing to multicollinearity issue that aroused by annexation of two liquidity measurement of the stock market: market capitalization ratio to GDP and turnover ratio in the same regression equation. The study applied time series data to make statistical inferences, applying quarterly or monthly data in the context of both countries would provide more robust estimation to affirm that the assertion made from finding was not enervated by number of observation.

\section{COMPETING INTERESTS}

Authors have declared that no competing interests exist.

\section{REFERENCES}

1. Yartey CA, Adjasi CK. Stock market development in Sub-Saharan Africa: Critical issues and challenges; 2007. International Monetary Fund, Working Paper Series, 207.

2. Frarren D. International administration; 2014. Accessed $30^{\text {th }}$ September, 2017. Available:http://www.africastriclybusiness.c om/list/africa-equity.mkt.cap

3. Onasanya OK, Ayoola FJ. Does macroeconomic variables have effect on stock market movement in Nigeria? Journal of Economics and Sustainable Development. 2012;3(10):25-36.

4. Adenuga AO. Stock market development indicators and economic growth in Nigeria: Empirical investigation. Central Bank of Nigeria, Economic and Financial Review. 2010;48(1):33-711.

5. Okonkwo $\mathrm{VI}$, Ananwude AC, Echekoba FN. Nigeria stock market development and economic growth: A time series analysis (1993 - 2013). Scholars Journal of Economics, Business and Management. 2015;2(3):280-293.

6. Adigwe PK, Nwanna IO, Ananwude AC. Stock market development and economic growth in Nigeria: An empirical examination (1985-2014). Journal of Policy and Development Studies. 2015;9(5):134154.

7. Echekoba FN, Ananwude AC. The linkage between the depth of development in Nigerian stock market and economic growth: A Johansen co-integration approach (1981-2015). Frontiers of Accounting and Finance. 2016;1(1):16-28.

8. Shaibu IB, Osemwengie PK, Oseme SA. Capital market activities and economic growth in Nigeria: Further evidence from VAR methodology. International Journal of Business and Management Review. 2014;2(3):32-47.

9. Andohol J, Gbahabo P. Assessment of the contributions of capital market to economic growth in Nigeria: A VECM approach. Nigerian Journal of Management Sciences. 2013;3(1):160-171.

10. Kapingura FM. Finance and economic growth nexus: Complementarity and 
substitutability between the banking sector and financial markets in Africa, using South Africa as a case. Journal of Economics and International Finance. 2013;5(7):273-286.

11. Gondo J. Financial development and economic growth: Evidence from South Africa. A Dissertation presented to the Department of Economics, University of South Africa; 2009.

12. Chipaumire G, Ngirande H. How stock market liquidity impact economic growth in South Africa. Journal of Economics. 2014;5(2):185-192.

13. Nduka EK, Anigbogu UE, Nyiputen IR. Investigating the causal relationship between stock market and aggregate economic performance of South Africa Asian Economic and Financial Review. 2016;6(4):218-227.

14. Odihiambo NM. Stock market development and economic growth in South Africa: An ARDL-Bond Testing Approach; 2009. Accessed $30^{\text {th }}$ September, 2017.

Available:https://www.wbiconpro.com/2.Nic holas.pdf

15. Ndako UB. Financial development, economic growth and stock market volatility: Evidence from Nigeria and South Africa. A dissertation submitted to the Department of Economics, University of Leicester, England; 2008.

16. Sinha A, Joshi A, Venkataraman A, Padmanabhan D, Ravi A. Analysis of volatility of stock markets in Russia, South Africa, China, Brazil and Argentina; 2015. Accessed $30^{\text {th }}$ September, 2017. Munich Personal RePEc Archive.

Available: https://mpra.ub.unimuenchen.de/63440/

17. Bano S, Kumarasinghe S, Tang YP. Comparative economic performance and stock market performance: Some evidence from the Asia-Pacific region. Asian Journal of Finance \& Accounting. 2011;3(1):103124.

18. Jalloh M. Does stock market capitalization influences economic growth in Africa?: Evidence from panel data. Applied Economics and Finance. 2015;2(1):91101.

19. Ruwaydah A, Ushad SA. Effects of stock market development on economic growth: The case of SADC countries; 2015. Proceedings of the Third Middle East Conference on Global Business, Economics, Finance and Banking (ME15
Dubai October Conference), 16-18 October. Paper ID: DF501.

20. Ngongang E. Financial development and economic growth in Sub Saharan Africa: A dynamic panel data analysis. European Journal of Sustainable Development. 2015;4(2):369-378.

21. Schumpeter JA. The theory of economic development. Cambridge. MA: Harvard University Press; 1912.

22. Cavenaile L, Gengenbach C, Palm F. Stock markets, banks and long run economic growth: A panel co-integrationbased analysis; 2011. Centre de Recherche en Economie Publique et de la Population CREPP WP No 2011/02.

23. Emeh Y, Chigbu EE. The impact of capital market on economic growth: The Nigerian perspective. International Journal of Development and Sustainability. 2014;3(4):838-864.

24. Seetanah B, Sawkut R, Sannasee V, Seetanah B. Stock market development and economic growth: Evidence from panel VAR framework; 2010. Accessed $30^{\text {th }}$ September, 2017.

Available: http//www.ssrn.com

25. Osakwe $\mathrm{Cl}$, Ananwude AC. Stock market development and economic growth in Nigeria: A camaraderie reconnaissance. Research Journal of Economics. 2017;1(1):78-90.

26. McKinnon RI, Shaw ES. Money and capital in economic development. Washington, DC: Brookings Institution; 1973.

27. Goldsmith RW. Financial structure and development. New Haven, CT: Yale University Press; 1969.

28. Okpara GC. Analysis of capital market performance and the growth of the Nigerian economy: A co-integration Approach. Global Journal of Human Social Science. 2010;10(4):9-15.

29. Atoyebi KO, Ishola SA, Kadiri KI, Adekunjo FO, Ogundeji MO. Capital market and economic growth in Nigeria: An empirical analysis. Journal of Humanities and Social Sciences. 2013;6(6):60-68

30. Ologunwa OP, Sadibo OV. Capital market development and economic growth in Nigeria: an empirical analysis. FUTA Journal of Management and Technology Maiden Edition. 2016;48-59.

31. Sa'adu AH. Impact of capital market performance on economic growth in Nigeria. A thesis submitted to the Department of Business Administration, 
Ahamdu Bello Uinversity, Zaria, Nigeria; 2014.

32 Oke MO. Nigeria capital market operation and economic growth: A case of the oil and gas sector. Asian Journal of Business and Management Sciences. 2012;1(8):62-72.

33. Ifionu EP Omojefe GO. The capital market and performance of the Nigerian economy: A time series analysis. West African Journal of Industrial and Academic Research. 2012;8(1):192-207.

34. Echekoba FN, Ezu GK, Egbunike CF. The impact of capital market on the growth of the Nigerian economy under democratic rule. Arabian Journal of Business and Management Review. 2013;3(2):53-62.

35. Edame GE, Okoro U. The impact of capital market and economic growth in Nigeria. Public Policy and Administration Research. 2013;3(9):7-15.

36. Kolakpo T, Adaaramola AO. The impact of capital market on economic growth. International Journal of Developing Societies. 2012;1(1):11-19.

37. Ogege S, Ezike JE. The Nigerian capital market and economic development: A critical appraisal. International Business Research. 2012;5(8):228-236.

38. Khetsi QS, Mongal, IP. The impact of capital markets on the economic growth in South Africa. Journal of Governance and Regulation Issues. 2015;4(1):1-16.

39. Alajekwu UB, Achugbu AA. The role of stock market development on economic growth in Nigeria: A time series analysis. African Research Review. 2012;6(1):5170.

40. Odo SI, Anoke Cl, Onyeisi OS, Chukwu BC. Capital market indicators and economic growth in Nigeria: An Autoregrssive Distributed Lag (ARDL) model. Asian Journal of Economics, Business and Accounting. 2017;2(3):1-16.

41. Josiah M, Samson AA, Akpeti OE. Capital market as a veritable source of development in Nigerian economy. Journal of Accounting and Taxation. 2012;4(1):718.
42. Karim S, Chaudhary GM. Effect of stock market development on economic growth of major South Asian and East Asian economies: A comparative analysis. Journal of Business Studies Quarterly. 2017;8(3):81-88.

43. Rousseau PL, Wachtel P. Equity market and growth: Cross-country evidence on timing and outcomes 1980-1995. Journal of Banking and Finance. 1999;24:19331957.

44. Bilal L, Chen S, Komal B. Impact of stock market development on economic growth: Evidence from lower middle income countries. Management and Administrative Sciences Review. 2016;5(2):86-97.

45. Ahmad Z, Khan AA, Tariq A. Stock market development and economic growth: A comparative study of Pakistan and Bangladesh. African Journal of Business Management. 2011;6(8):2985-2989.

46. Chang SC. Stock market development and economic growth: A panel data approach. Asia Pacific Management Review. 2011;6(3):357-376.

47. Hailemariam A, Guotai C. Stock market development and economic growth: Empirical evidence for emerging market economies. International Journal of Economics, Finance and Management Sciences. 2014;2(2):171-181.

48. Azam M, Haseeb M, Samsi AB, Raji JO. Stock market development and economic growth: Evidences from Asia-4 countries. International Journal of Economics and Financial Issues. 2016;6(3):1200-1208.

49. Okoro GE. Stock market performance and the augmentation of frontier economies: A comparative scrutiny of Nigeria and Mauritius. Studies and Scientific Researches Economics Edition. 2016;23:13-20.

50. Altarturi BHM, Abduh M. Stock markets and economic growth: a comparative analysis between Islamic and conventional markets in Malaysia. Middle East Journal of Management. 2016;3(1):34-48.

(C) 2017 Osakwe and Ananwude; This is an Open Access article distributed under the terms of the Creative Commons Attribution License (http://creativecommons.org/licenses/by/4.0), which permits unrestricted use, distribution, and reproduction in any medium, provided the original work is properly cited.

Peer-review history:

The peer review history for this paper can be accessed here: http://sciencedomain.org/review-history/22182 